\title{
Psychiatric disorders seen in correlation with epileptic seizures
}

\author{
Amitabh Saha \\ Department of Psychiatry, Command hospital, Pune- 40, India \\ Email address: \\ sahaing@gmail.com
}

To cite this article:

Amitabh Saha. Psychiatric Disorders Seen in Correlation with Epileptic Seizures. American Journal of Life Sciences.

Vol. 2, No. 2, 2014, pp. 108-116. doi: 10.11648/j.ajls.20140202.22

\begin{abstract}
Psychiatric morbidity in cases of epilepsy are frequently seen in our clinical practice. Epileptic seizures and subsequent sequelae leave behind triggers for development of psychiatric disorders. Among the commonly seen psychiatric disorders are depression, psychosis, personality disorders and various other phenomenology's which is cited in this article.
\end{abstract}

Keywords: Epilepsy, Psychosis, Epileptic Personality, Depression, Catastrophic Reaction, Psychiatric Morbidity

\section{Introduction}

The study of epilepsy and the disorders related to it calls for a broad perspective and knowledge of natural events that leads to its etiology. The outstanding characteristic of the epileptic fit is its recurrence. Throughout centuries, epilepsy has enjoyed a pride of place as judged by medical writing that have survived. The history of epilepsy is intimately interwoven with conceptions of the cause of convulsion, their cure, and the treatment of the persons inflicted. With all this is also linked our understanding of the disease, the various morbidity associated with epilepsy, including the psychiatric morbidity [1].

Epileptic disorders were initially thought to be psychiatric ailments where the body of the person was possessed by demons signifying their total control of the human body and their psyche by causing involuntary convulsive events.[2] A modern view of epilepsy and mental illness evolved. It states that people with epilepsy are normal mentally, but it is brain damage and the site of the lesion that leads to an association between epilepsy and mental illness. [3]. various researchers concentrated on heterogeneous manifestation associated with epilepsy, such as schizophrenia form psychosis [4], sexual disorders [5], behavior disorders and criminality [6]. Case reports have appeared in literature about epileptics presenting as catatonic stupor [7, 8]. Many studies have attempted to assess whether patients with epilepsy, when tested on personality rating scales, show different profiles from those without epilepsy. Generally, the results support the hypothesis that patients with epilepsy have abnormal personalities. However, this outcome may be attributed to many biological variables, for example, head injury following recurrent seizures, or the prescription of long term anticonvulsant drugs, which may lead to behavioral change. In addition, it may relate to psychosocial variables, such as stigmatization and a low expectancy of achievement by the family or by teachers. Description of traits specific to the 'epileptic personality' include the adjectives 'pedantic', 'circumstantial', 'adhesive' or 'viscous' [9]. Pond and Bidwell's seminal study in general practice identified psychiatric problems in about one third of patients. Half the group showed neurotic symptoms [10].

There is much evidence that both children and adults have a greater prevalence of psychiatric disorder that cannot be directly related to a seizure occurrence. However, recent studies have reported a similar prevalence of minor mental illnesses in randomly selected, non-epileptic populations [11].

In a majority of the studies, definite conclusions are impeded by methodological limitations. The work has been carried out in hospitals in populations that are expected to contain an excess of disturbed patients. The subjects with epilepsy (in general, patients with mixed seizure disorders, from psychiatric series or with temporal lobe epilepsy) may not be representative of the epileptic population at large. Moreover, studies have tended to be non-representative, not having diseased and healthy controls. The types of epilepsy or the psychiatric morbidity under study have been compartmentalized. This study addresses a few of these shortcomings. The patients are both in- and out-patients in a general hospital setup. Lastly, incorporating a 
representative, random sample with both healthy and disease controls with standardized interpretation of data aims to make this study epidemiologically sound.

\subsection{Review of Literature}

The word epilepsy has been derived from Greek words meaning "to seize upon" or "take a hold of". Epilepsy has been defined as an intermittent derangement of the nervous system presumably due to sudden, excessive, disorderly discharge of cerebral neurons. The discharge results in an almost instantaneous disturbance of sensation, loss of consciousness, impairment of psychic function, convulsive movements, or some combination thereof [12].

Behavioral changes in patients with epilepsy have been identified for many years. These range from depression and anxiety to psychosis, and include some specific personality problems that have variously been referred to as the interictal personality disorder of epilepsy and the GastautGeschwind syndrome.

Epilepsy for which no pathologic basis has been established and which there is no apparent underlying cause except perhaps a genetic one are called primary or essential. Included in this category are hereditary forms, such as generalized tonic clonic seizures (grand mal) and absence seizure states.

\subsection{Psychiatric Morbidity in Epilepsy}

Epilepsy is important to the psychiatric and the psychiatrist is important to epilepsy. Epileptic activity in the brain has an effect on the behavior, mood and cognitive functions of the patient. His behavior and mood may be affected by the attitudes of others to his disability, and the patient's social and psychological adaptations may further modify his epileptic experiences [13].

Pond and Bidwell (1959) carried out a community study in England amongst epileptics seen in General practice in 218 patients. They reported a prevalence of $29 \%$ for 'psychological difficulties' and $15 \%$ of their subject showed neurotic symptoms. The patients were not compared with any other group and the principal worker was unable to interview all the patients, relying on the General Practitioners for the diagnosis [11].

Jensen and Larsen (1979) studied 74 patients with drug resistant temporal lobe epilepsy. They reported that $85 \%$ had psychiatric disorders ranging from behavior disturbances $(72.9 \%)$, psychoses and attempted suicide $(14.8 \%)$, neurosis $(9.4 \%)$, sexual aggression $(5.4 \%)$, drug and alcohol abuse (4.05\%) and 'miscellaneous'(36. 48\%) [14].

\subsection{Epilepsy and Depression}

Depression is a clinically important concomitant of epilepsy. Depression is known to occur with the epileptic ictus as prodrome, aura, and post-ictal experience [15] as also interictally [16]. Some investigators have found that interictal depression is more common in epileptics with temporal lobe foci. Williams (1956) in 2000 personally seen patients with epilepsy found $5 \%$ of them felt emotion as a part their attack. Of these 61 had ictal fear, 21 ictal depressions and 18 some other ictal emotions [17].

Fiordelli (1993) studied one hundred patients with cryptogenic and normal intelligence and 100 age and sex matched controls using the Clinical Interview Schedule. The patients were seen in a regional epilepsy center over a period of three years. The psychiatric diagnosis was made using DSM-IIIR criteria. Depressive thought content and depression accounted for $62 \%$ of the symptom score, and $40 \%$ of the patients were observed to be depressed [18].

The importance of understanding depression in epilepsy is highlighted when the frequency of suicide / parasuicides, in this population is considered. Having reviewed 11 previous studies, Barraclough reported a suicide rate five times the general population [19]. The social sequalae were relevant more than 2000 years ago when Hippocrates referred to the condition as the "sacred disease. Since that time, much has been written on the social stigmatization of those with epilepsy, even in our more enlightened times, there is evidence that this stigmatization persists [20]. The most powerful means of reducing this prejudice is through educating the patients, their families, and the public about epilepsy.

The role of temporal lobes in the generation of affective states may also be investigated by considering the effects of temporal lobe surgery performed for the control of epilepsy. Of the 72 patients followed post-surgically for 1-2 years, six made suicide attempts, and in every case, this was in the first month after the operation [31].

\subsection{Epilepsy and Psychosis}

According to the conventional usage, the term 'psychoses of epilepsy' applies to certain abnormal mental states and disorders and disorders associated, or a part of seizure disorders.

Perez and Trimble (1980) studied the mental states of 23 epileptic psychotic patients and 10 patients with process schizophrenia using the present state examination. The epileptics displayed marked heterogeneity of psychiatric diagnoses. Disturbances of affect underlying the psychosis or presenting as manic-depressive psychosis were frequent and independent of the type of epilepsy. Schizophrenia psychosis was also significantly associated with temporal lobe epilepsy [5].

Toone et al (1982) compared 69 patients having a combined diagnosis of epilepsy and psychosis with 53 patients with a diagnosis of functional psychosis. The epileptic affective patients often lacked convincing psychotic features. Electroconvulsive Therapy and Lithium were rarely prescribed. Only three showed evidence of bipolarity. The epileptic schizophrenic patients were judged to have the better premorbid personality, experience more paranoid and referential delusions. They showed fewer catatonic features than the functional schizophrenics did and the course of the illness was more variable. They 
supported the concept of a schizophrenia-like psychosis as a distinct nosological entity, but entity, but not affective psychosis and epilepsy [118].

Continuous auras have been described as the appearance of prolonged auras following the successful institution of anticonvulsant therapy by Scott and Masland [21]. 12 out of a consecutive series of 100 patients were so afflicted. Elementary sensory and motor auras were described, but visual and psychic auras were the most commonly encountered. The majority of patients had temporal lobe foci.

The psychopathology of postictal psychosis is polymorphic, but most patients present with abnormal mood and paranoid delusions [22]. Some patients are confused throughout the episode; others present with fluctuating impairment of consciousness and orientation. Sometime there is no confusion whatsoever.

Interictal psychoses occur between seizures and cannot be linked directly to the ictus. They are also frequent than the peri-ictal psychoses and account for $10.30 \%$ of diagnosis in unselected case series. Interictal psychoses are, however, clinically more significant in terms of severity and duration than peri-ictal psychoses, which are short lasting and often self-limiting.

\subsection{Epilepsy and Other Psychiatric Disturbances}

Automation is perhaps the most important behavioral manifestation of partial seizure discharge from the psychiatric point of view. Epileptic automatism may be defined as a state of clouding of consciousness which occurs during or immediately after a seizure discharge and during which the individual retains control of posture and muscle tone without being aware of what is happening. It may occur either as a direct result of a seizure discharge or a post ictal event following any kind of fit. Automatic acts, if occurring, are short lived, fragmentary and non-sustained, confirming the view that seriously aggressive behavior is rare during epileptic seizures [23].

Mania is rarely associated with epilepsy. Williams described elation in just three of 2000 patients [17]. The few cases reported in literature are in the form of anecdotal accounts of individual cases [24].

Hooshmand Brawley described three patients who showed exhibitionist behavior because of undressing during epileptic automatisms. In a patient with temporal lobe epilepsy, partial seizures were triggered of by orgasm.

Much more common in patients with epilepsy are complaints of reduced libido and impotence. Toone (1980) carried out a study of the relationship between sexual function, sex hormone levels and medication [24]. Estimation of free testosterone circulating in the serum of chronic epileptics was lower than those of controls. The relation between epilepsy and personality disturbance has been a controversial one. Scott [25] recognized both periictal and interictal problems defining patients who entered a prolonged abnormal mental state, "folie epileptique" in which slight epileptic paroxysms could be unrecognized or were substituted for by the abnormal mental state.

\section{Materials and Methods}

It was carried out in a large urban referral hospital.

Subjects: The patients were those attending the OPDs of the departments of Neurology and Dermatology as well as patients hospitalized in the wards.

Group A: One hundred cases of epilepsy satisfying the following criteria comprised the study group.

(a) Age between 18 and 50 years

(b) Clinical diagnosis of idiopathic epilepsy corroborated by abnormal EEG[s]

(c) No evidence of a structural cerebral disorder

(d) No evidence of mental sub normality

(e) No evidence of a psychiatric disorder preceding the onset of epilepsy

(f) No evidence of other major medical disorder

Group B: To control for the non-specific, psychological effects of a chronic, socio-occupationally disabling disease one hundred age, sex and education matched patients of Leprosy were included using the above criteria as the comparison group.

Group C: A third group of similarly age, sex and education matched one hundred healthy individuals who also satisfied the aforementioned criteria comprised the control group.

Performa: The subjects of the three groups were interviewed, their consent for the study obtained and their socio-demographic and other data relevant to the study documented in a specially designed proforma.

Method: The subjects underwent the following assessments:

1. Recording of demographic profile and relevant medical history as per the Performa.

2. Perusal of case and other related documents.

3. A detailed clinical and neurological examination.

4. Initial screening to detect Psychiatric Morbidity in all three groups was carried out suing 30 items General Health Questionnaire [GHQ]. The GHQ was designed to be a self-administered screening test aimed at detecting psychiatric disorders amongst respondents in a community setting and non-psychiatric clinical settings. It is aimed at detecting those forms of psychiatric disorder that may have a relevance to a patient's presence in a medical clinic. GHQ -30, in particular has a high sensitivity to detect depression. Goldberg [109] gives a modal value of $4 / 5$ for $87 \%$ specificity and $91.4 \%$ sensitivity in detecting casernes. Scoring was done by the GHQ method that reduces the bias associated with the bimodal response scales. Those with a score of five or more were considered to have a psychological morbidity [26].

5. The subjects scoring above 5 on the GHQ were considered possible psychiatric cases and were then interviewed using Schedules for Clinical 
Assessment in Neuropsychiatry (SCAN).

Statistical analysis: Statistical analysis was carried out using chi square test for the raw sample as well as for the linear trend and the stratum odds ratio.

\section{Results and Observations}

Three hundred subjects were selected for the study out of which one hundred were cases of epilepsy [Group A], one hundred patients of Leprosy [Group B] and one hundred normal healthy individuals [Group C]

Table 1. Age Distribution [N=300].

\begin{tabular}{llll}
\hline AGE & $\begin{array}{l}\text { Epilepsy } \\
\text { Group A } \\
{[\mathrm{n}=100]}\end{array}$ & $\begin{array}{l}\text { Leprosy } \\
\text { Group B } \\
{[\mathrm{n}=100]}\end{array}$ & $\begin{array}{l}\text { Normal } \\
\text { Group C } \\
{[\mathrm{n}=100]}\end{array}$ \\
\hline $18-25$ & 26 & 26 & 26 \\
$>25-32$ & 32 & 32 & 32 \\
$>32-39$ & 22 & 22 & 22 \\
$>39-46$ & 10 & 10 & 10 \\
$>46$ & 10 & 10 & 10 \\
Total & 100 & 100 & 100 \\
\hline
\end{tabular}

Age: Table I give the age distribution in the various groups. The age of the cases ranged from 18-50 years, with a mean of 31.83 years [SD 9.46] in Group A, 31.81 years [SD 8.97] in group B and 31.76 years [SD 8.85] in group c.

Table 2. Age Related Morbidity Epilepsy.

\begin{tabular}{|c|c|c|c|c|}
\hline \multicolumn{5}{|c|}{ PSYCHIATRIC DISORDER } \\
\hline Age & TOTAL & PRESENT & ABSENT & $\begin{array}{l}\text { STRATUM } \\
\text { ODD'S RATIO }\end{array}$ \\
\hline $18-25$ & 26 & $6(23.1 \%)$ & $20(76.9 \%)$ & 1.00 \\
\hline$>25-32$ & 32 & $18(56.25 \%)$ & $14(43.75 \%)$ & 4.29 \\
\hline$>32-39$ & 22 & $10(45.5 \%)$ & $12(54.5 \%)$ & 2.78 \\
\hline$>39-46$ & 10 & $8(80 \%$ & $2(20 \%)$ & 13.33 \\
\hline$>46$ & 10 & $2(20 \%)$ & $8(80 \%)$ & 0.00 \\
\hline
\end{tabular}

Chi Square $($ Linear Trend $)=21.645 \quad \mathrm{P}<0.001$

The psychiatric morbidity varied from $20 \%$ in the above 46 age group to $80 \%$ in the $>39-46$ years old. The chi square for linear tend is highly significant.

Table 3. Sex Distribution $[N=300]$.

\begin{tabular}{llll}
\hline & $\begin{array}{l}\text { Epilepsy } \\
\text { Group A } \\
{[\mathrm{n}=100]}\end{array}$ & $\begin{array}{l}\text { Leprosy } \\
\text { Group B } \\
{[\mathrm{n}=100]}\end{array}$ & $\begin{array}{l}\text { Normal } \\
\text { Group C } \\
{[\mathrm{n}=100]}\end{array}$ \\
\hline Males & 82 & 82 & 82 \\
Females & 18 & 18 & 18 \\
Total & 100 & 100 & 100 \\
\hline
\end{tabular}

Sex: There were 82 males in each group and 18 females. This selection bias was because the hospital catered to a predominantly male population as shown in Table 3 .

Table 4. Gender Related Morbidity $(n=100)$.

\begin{tabular}{llll}
\hline \multicolumn{2}{l}{ PSYCHIATRIC DISORDER } & \\
& TOTAL & PRESENT & ABSENT \\
\hline MALES & 82 & $34(41.5 \%)$ & $48(58.5 \%)$ \\
FEMALES & 18 & $10(55 \%)$ & $8(45 \%)$ \\
\hline
\end{tabular}

Chi-Square $=1.18 \quad \mathrm{Df}=1 \quad \mathrm{P}<0.2$ (Not Significant)

Psychiatric morbidity was present in $41.5 \%$ of the male epileptics and 55\% of the females in Group A. The difference was not statistically significant (Table 4).

Table 5. Education [N=300].

\begin{tabular}{llll}
\hline $\begin{array}{l}\text { EDUCATIONAL } \\
\text { STATUS }\end{array}$ & $\begin{array}{l}\text { Epilepsy } \\
\text { Group A } \\
{[\mathrm{n}=100]}\end{array}$ & $\begin{array}{l}\text { Leprosy } \\
\text { Group B } \\
{[\mathrm{n}=100]}\end{array}$ & $\begin{array}{l}\text { Normal } \\
\text { Group C } \\
{[\mathrm{n}=100]}\end{array}$ \\
\hline Professional & 2 & 2 & 2 \\
Graduate & 15 & 15 & 15 \\
Twelfth & 18 & 18 & 18 \\
Tenth & 22 & 22 & 22 \\
Below tenth & 36 & 36 & 36 \\
Uneducated & 7 & 7 & 7 \\
Total & 100 & 100 & 100 \\
\hline
\end{tabular}

Education: Education wise distribution of the subjects is shown in Table 5. The educational status ranged from being uneducated to Post graduation/professional qualifications. The latter, for the purpose of the study were taken as equivalent.

Table 6. Education Related Morbidity Epilepsy (N=100).

\begin{tabular}{|c|c|c|c|c|}
\hline & \multicolumn{3}{|c|}{ PSYCHIATRIC DISORDER } & \multirow{2}{*}{$\begin{array}{l}\text { STRATUM } \\
\text { ODD'S } \\
\text { RATIO }\end{array}$} \\
\hline & $\begin{array}{l}\text { Total In } \\
\text { Group } \\
\text { A }\end{array}$ & PRESENT & ABSENT & \\
\hline Professional & 2 & $1(50 \%)$ & $1(50 \%)$ & \multirow{2}{*}{1.00} \\
\hline Graduate & 15 & $6(40 \%)$ & $9(60 \%)$ & \\
\hline Twelfth & 18 & $5(27.8 \%)$ & $13(72.2 \%)$ & 0.55 \\
\hline Tenth & 22 & $4(18.2 \%)$ & $18(81.8 \%)$ & 0.32 \\
\hline Below Tenth & 36 & $22(61.1 \%)$ & $14(38.9 \%)$ & 2.24 \\
\hline Uneducated & 7 & $6(85.7 \%)$ & $1(14.3 \%)$ & 8.57 \\
\hline
\end{tabular}

Chi Square $($ Linear trend $)=21.645 \mathrm{P}<0.001$

The psychiatric morbidity ranged from $18 \%$ in the subjects with epilepsy who had studied until Class Tenth to $85 \%$ in the uneducated. The Stratum Odds Ratio too showed a rising trend as the educational level declines. The observation was highly significant. 
Table 7. Correlation Of Age At Onset, Education And Psychiatric Disorder: Epilepsy (Group A) (N=100).

\begin{tabular}{|c|c|c|c|c|c|c|c|c|c|c|c|c|c|c|c|}
\hline \multirow{3}{*}{$\begin{array}{l}\text { AGE AT ONSET OF EPILEPSY (YEARS) } \\
\text { EDUCATION }\end{array}$} & \multirow{2}{*}{\multicolumn{3}{|c|}{$\begin{array}{c}<=25 \\
\text { PSYCHIAT } \\
\text { RIC } \\
\text { DISORDER }\end{array}$}} & \multirow{2}{*}{\multicolumn{3}{|c|}{$\begin{array}{c}26-32 \\
\text { PSYCHIAT } \\
\text { RIC } \\
\text { DISORDER }\end{array}$}} & \multirow{2}{*}{\multicolumn{3}{|c|}{$\begin{array}{c}>32-39 \\
\text { PSYCHIAT } \\
\text { RIC } \\
\text { DISORDE }\end{array}$}} & \multirow{2}{*}{\multicolumn{3}{|c|}{$\begin{array}{c}>39-46 \\
\text { PSYCHIAT } \\
\text { RIC } \\
\text { DISORDER }\end{array}$}} & \multirow{2}{*}{\multicolumn{3}{|c|}{$\begin{array}{c}>46 \\
\text { PSYCHIAT } \\
\text { RIC } \\
\text { DISORDER }\end{array}$}} \\
\hline & & & & & & & & & & & & & & & \\
\hline & $\stackrel{-1}{\stackrel{0}{9}}$ & $\begin{array}{l}\text { च } \\
\text { TI } \\
\text { N } \\
\text { 而 }\end{array}$ & 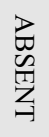 & 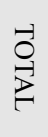 & 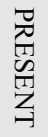 & 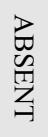 & 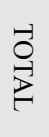 & $\begin{array}{l}\text { च } \\
\text { Tñ } \\
\text { N } \\
\text { 至 }\end{array}$ & $\begin{array}{l}\text { Z } \\
\text { N } \\
\text { TI } \\
Z\end{array}$ & $\stackrel{-1}{0}$ & 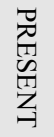 & $\begin{array}{l}\mathbb{Z} \\
\text { 足 } \\
\text { 艺 }\end{array}$ & 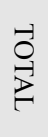 & 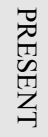 & $\begin{array}{l}\text { Z } \\
\text { 田 } \\
\text { 岂 }\end{array}$ \\
\hline UNEDUCATED & 1 & 0 & 1 & 5 & 5 & 0 & 0 & 0 & 0 & 1 & 1 & 0 & 0 & 0 & 0 \\
\hline $\begin{array}{l}\text { BELOW } \\
\text { TENTH }\end{array}$ & 15 & 8 & 7 & 5 & 5 & 0 & 11 & 7 & 4 & 1 & 0 & 1 & 4 & 2 & 2 \\
\hline TENTH & 8 & 0 & 8 & 12 & 4 & 8 & 2 & 0 & 2 & 0 & 0 & 0 & 0 & 0 & 0 \\
\hline TWELFTH & 12 & 2 & 10 & 2 & 2 & 0 & 3 & 1 & 2 & 1 & 0 & 1 & 0 & 0 & 0 \\
\hline $\begin{array}{c}\text { GRADU } \\
\text { ATE }\end{array}$ & 2 & 2 & 0 & 5 & 1 & 4 & 3 & 2 & 1 & 1 & 1 & 0 & 4 & 0 & 4 \\
\hline PROFESSIONAL & 0 & 0 & 0 & 1 & 1 & 0 & 0 & 0 & 0 & 1 & 0 & 1 & 0 & 0 & 0 \\
\hline TOTAL & 38 & 12 & 26 & 30 & 18 & 12 & 19 & 10 & 9 & 5 & 2 & 3 & 8 & 2 & 6 \\
\hline
\end{tabular}

A comparison of educational status, age at onset of epilepsy and psychiatric disorder shows that $57.8 \%$ patients whose epilepsy had started below the age of 25 years had completed at least ten years of formal education. A lower educational status was not, thus, necessarily consequent to an earlier onset of epilepsy. The maximum psychiatric morbidity (60\%) was if the illness began between 26-32 years.

Table 8. Socio Economic Status $(N=100)$.

\begin{tabular}{llll}
\hline & $\begin{array}{l}\text { Epilepsy } \\
\text { Group } \\
\text { A) }\end{array}$ & $\begin{array}{l}\text { Leprosy } \\
\text { Group } \\
\text { B) }\end{array}$ & $\begin{array}{l}\text { Normal } \\
\text { Group } \\
\text { C) }\end{array}$ \\
\hline $\begin{array}{l}\text { Upper Socio } \\
\begin{array}{l}\text { Economic(USE) } \\
\text { Upper Middle Socio }\end{array}\end{array}$ & 3 & 0 & 2 \\
$\begin{array}{l}\text { Economic (USME) } \\
\text { Lower Middle Socio }\end{array}$ & 6 & 0 & 1 \\
$\begin{array}{l}\text { Economic (LMSE) } \\
\text { Upper Lower Socio }\end{array}$ & 84 & 76 & 86 \\
$\begin{array}{l}\text { Economic (ULSE) } \\
\text { Lower socio Economic } \\
\text { (LSE) }\end{array}$ & 4 & 12 & 4 \\
Total & 100 & 12 & 7 \\
\hline
\end{tabular}

Socio-economic status: The socio-economic distribution of the sample is shown in Table 7. A majority of the subjects was in the Lower Middle Socio-economical group.

Table 9. Socio-Economic Status Related Morbidity Epilepsy (N=100).

\begin{tabular}{|c|c|c|c|c|}
\hline & \multicolumn{3}{|c|}{ Psychiatric Disorder } & \multirow{2}{*}{$\begin{array}{l}\text { Stratum } \\
\text { Odd'S Ratio }\end{array}$} \\
\hline & $\begin{array}{l}\text { Total In } \\
\text { Group A }\end{array}$ & Present & Absent & \\
\hline USE & 3 & $0(0 \%)$ & $3(100 \%)$ & \multirow{2}{*}{1.00} \\
\hline UMSE & 6 & $4(66.7 \%)$ & $2(33.3 \%)$ & \\
\hline LMSE & 84 & $34(40.5 \%)$ & $50(59.5 \%)$ & 0.85 \\
\hline ULSE & 3 & $2(66.7 \%)$ & $1(33.3 \%)$ & \multirow{2}{*}{7.5} \\
\hline LSE & 4 & $4(100 \%)$ & $0(0 \%)$ & \\
\hline
\end{tabular}

The psychiatric morbidity ranged from none in the Upper Socioeconomic to $100 \%$ in the Lower Socioeconomic group. Though the Odds ratio showed an increase probability for lower socioeconomic group to develop a psychiatric morbidity, the chi-square for linear trend, and the $p$ value, is not significant.

Table 10. Duration of Epilepsy $[n=100]$.

\begin{tabular}{lllll}
\hline $\begin{array}{l}\text { Duration of } \\
\text { Illness }\end{array}$ & $\begin{array}{l}\text { Psychiatric } \\
\text { Disorder } \\
\text { Present }\end{array}$ & $\begin{array}{l}\text { Psychiatric } \\
\text { Disorder } \\
\text { Absent }\end{array}$ & $\begin{array}{l}\text { Total } \\
\text { Number in } \\
\text { Group A }\end{array}$ & $\begin{array}{l}\text { Stratum } \\
\text { Odds } \\
\text { Ratio }\end{array}$ \\
\hline $\begin{array}{l}<\text { Month to } 6 \\
\text { Months }\end{array}$ & 6 & 16 & 22 & 1.00 \\
$>6$ Months to & 10 & 20 & 30 & 1.33 \\
$\begin{array}{l}\text { Y Years } \\
>1 \text { Years to }\end{array}$ & 11 & 6 & 17 & 4.89 \\
$\begin{array}{l}3 \text { Years } \\
>3 \text { Years to }\end{array}$ & 9 & 4 & 13 & 6.00 \\
5 Years & 8 & 10 & 18 & 2.13 \\
$>5$ Years & & & & \\
Total & & & & \\
\hline
\end{tabular}

Chi square Linear Trend $=4.01 \quad \mathrm{P}<0.05$ [Significant]

Duration of Illness: The duration of epilepsy in the subjects of Group A ranged from less than one month to twenty-seven years. The data is as depicted in Table 9.

Table 11. Duration Of Leprosy Group B $(n=100)$.

\begin{tabular}{ll}
\hline Duration of Leprosy & Total number \\
\hline$<6$ months & 23 \\
6 months -1 Year & 13 \\
1 Year -2 Years & 37 \\
$>2$ Years & 27 \\
\hline
\end{tabular}

The duration of Leprosy range from a fortnight to 4 years as shown in Table 11. 
Table 12. Psychiatric Disorder.

\begin{tabular}{|c|c|c|c|c|c|c|c|c|}
\hline \multirow[b]{2}{*}{ Duration of Illness } & \multicolumn{4}{|c|}{$\begin{array}{l}\text { Epilepsy (Group A) } \\
(\mathrm{n}=100)\end{array}$} & \multicolumn{4}{|c|}{$\begin{array}{l}\text { Leprosy (Group B) } \\
(\mathrm{n}=100)\end{array}$} \\
\hline & $\begin{array}{l}\text { Total in Group } \\
\text { A }\end{array}$ & \multicolumn{2}{|c|}{$\begin{array}{l}\text { Psychiatric } \\
\text { Disorder }\end{array}$} & $\begin{array}{l}\text { Stratum } \\
\text { Odds } \\
\text { Ratio }\end{array}$ & $\begin{array}{l}\text { Total in } \\
\text { Group } \\
\text { B }\end{array}$ & \multicolumn{2}{|c|}{$\begin{array}{l}\text { Psychiatric } \\
\text { Disorder }\end{array}$} & $\begin{array}{l}\text { Stratum } \\
\text { Odds } \\
\text { Ratio }\end{array}$ \\
\hline$<1$ Month to 6 Month & 22 & 6 & 16 & 1.00 & 23 & 7 & 16 & 1.00 \\
\hline $\begin{array}{l}>6 \text { Months to } \\
1 \text { Year }\end{array}$ & 30 & 10 & 20 & 1.33 & 13 & 2 & 11 & 0.42 \\
\hline$>1$ Year & 48 & 28 & 20 & \multirow{2}{*}{3.73} & 64 & 10 & 54 & \multirow{2}{*}{0.42} \\
\hline Total & 100 & 44 & 56 & & 100 & 19 & 81 & \\
\hline
\end{tabular}

A correlation of psychiatric disorders in Group A (Epilepsy) and Group B (Leprosy) shows that unlike the former, the latter has no rising trend as the duration of illness increases. The longer duration of epilepsy necessitated combination of all epileptics with duration of illness greater than one year.

Table 13. GHQ Score $[n=300]$.

\begin{tabular}{lllll}
\hline $\begin{array}{l}\text { GHQ } \\
\text { Score }\end{array}$ & $\begin{array}{l}\text { Epilepsy } \\
\text { Group A } \\
{[\mathrm{n}=100]}\end{array}$ & $\begin{array}{l}\text { Leprosy } \\
\text { Group B } \\
{[\mathrm{n}=100]}\end{array}$ & $\begin{array}{l}\text { Normal } \\
\text { Group C } \\
{[\mathrm{n}=100]}\end{array}$ & $\begin{array}{l}\text { Stratum } \\
\text { Odds } \\
\text { Ratio }\end{array}$ \\
\hline$<5$ & 56 & 81 & 96 & 1.00 \\
5 to 10 & 26 & 10 & 4 & 3.38 \\
11 to 15 & 4 & 4 & 0 & 1.43 \\
16 to 20 & 10 & 3 & 0 & 4.76 \\
$>20$ & 4 & 2 & 0 & 2.86 \\
Total & 100 & 100 & 100 & \\
\hline
\end{tabular}

Chi Square Linear Trend $=8.97 \mathrm{P}<0.01$ [Highly Significant]

Epilepsy/Leprosy: Chi Square $=14.75, \mathrm{df}=4, \mathrm{p}<0.05$ [Significant]

Epilepsy/Normal: Chi Square $=4.66 \mathrm{df}=4, \mathrm{p}<0.0001[$ Very highly Significant]

Leprosy/ Normal: Chi Square $=13.73, \mathrm{df}=4, \mathrm{p}<0.01$ [Significant]

GHQ Scores: The distribution of GHQ scores in the three group is as shown in Table 12. The presumed psychiatric morbidity is 44\% (Group A), 19\% (Group B) and 4\% (Group C).

Table 14. Psychiatric Morbidity $(N=300)$.

\begin{tabular}{llll}
\hline & $\begin{array}{l}\text { EPILEPSY } \\
\text { Group A } \\
{[\mathrm{n}=100]}\end{array}$ & $\begin{array}{l}\text { EPILEPSY } \\
\text { Group B } \\
{[\mathrm{n}=100]}\end{array}$ & $\begin{array}{l}\text { NORMAL } \\
\text { Group C } \\
{[\mathrm{n}=100]}\end{array}$ \\
\hline $\begin{array}{l}\text { Psychiatric Disorder } \\
\text { Present }\end{array}$ & 44 & 19 & 4 \\
$\begin{array}{l}\text { Psychiatric Disorder } \\
\text { Absent }\end{array}$ & 56 & 81 & 96 \\
Total & 100 & 100 & 100 \\
\hline
\end{tabular}

Chi Square $=47.08 \quad \mathrm{Df}=2 \quad \mathrm{P}<0.0001$ [Very Highly Significant]
Epilepsy/Leprosy: Chi Square $=14.48, \quad \mathrm{Df}=1 \mathrm{p}<0.0$ 01[Highly Significant]

Epilepsy/Normal: Chi Square $=41.69$, Df $=1$ $\mathrm{p}<0.0001$ [Very highly Significant]

Leprosy/ Normal: Chi Square $=9.63, \quad \mathrm{Df}=1 \mathrm{p}<0.1$ [Significant]

Psychiatric Morbidity: The various disorders as diagnosed using SCAN are as shown in Table 13 and 14.

Table 15: Psychiatric Disorders

\begin{tabular}{|c|c|c|c|}
\hline Psychiatric disorder & $\begin{array}{l}\text { Epilepsy } \\
(\mathrm{n}=44)\end{array}$ & $\begin{array}{l}\text { Lepros } \\
\mathrm{y} \\
(\mathrm{n}=19)\end{array}$ & $\begin{array}{l}\text { Norma } \\
1 \\
(\mathrm{n}=4) \\
\end{array}$ \\
\hline $\begin{array}{l}\text { Organic Delusional [Schizophrenia } \\
\text { like] disorder F06.2 }\end{array}$ & 2 & 0 & 0 \\
\hline $\begin{array}{l}\text { Cannabinoid Dependence Syndrome } \\
\text { F12.2 }\end{array}$ & 1 & 0 & 0 \\
\hline $\begin{array}{l}\text { Severe Depressive Episode with } \\
\text { psychiatric features F } 32.3\end{array}$ & 0 & 1 & 0 \\
\hline $\begin{array}{l}\text { Moderate Depressive Episode with } \\
\text { somatic syndrome F } 32.11\end{array}$ & 15 & 7 & 0 \\
\hline Dysthymia F 34.1 & 6 & 1 & 4 \\
\hline Panic Disorder F 41.1 & 4 & 0 & 0 \\
\hline Generalized Anxiety Disorder F 41.1 & 1 & 1 & 0 \\
\hline $\begin{array}{l}\text { Mixed Anxiety Depressive Disorder F } \\
41.2\end{array}$ & 0 & 4 & 0 \\
\hline Post-Traumatic Stress Disorder F 43.1 & 1 & 0 & 0 \\
\hline $\begin{array}{l}\text { Adjustment Disorder Brief Depressive } \\
\text { Reaction F } 43.20\end{array}$ & 6 & 0 & 0 \\
\hline $\begin{array}{l}\text { Adjustment Disorder Prolonged } \\
\text { Depressive Reaction F } 43.21\end{array}$ & 3 & 4 & 0 \\
\hline Mixed Dissociative Disorder F 44.7 & 1 & 0 & 0 \\
\hline Somatization Disorder F 45.0 & 0 & 1 & 0 \\
\hline $\begin{array}{l}\text { Somatoform Autonomic Dysfunction } \\
\text { F } 45.38\end{array}$ & 2 & 0 & 0 \\
\hline $\begin{array}{l}\text { Persistent Somatoform Pain Disorder } \\
\text { F } 45.5\end{array}$ & 2 & 0 & 0 \\
\hline
\end{tabular}

The Pattern of disorder found in the three groups is shown in table 14. The commonest diagnosis in Group A (Epilepsy) was Moderate Depressive Episode with Somatic Syndrome (F32.11) in 15\% of the sample. Disorders with 
Affective symptomatology formed the largest proportion of illnesses.

Table 16. Seizure Related Morbidity $(N=100)$.

\begin{tabular}{llll}
\hline $\begin{array}{l}\text { Type of } \\
\text { seizure }\end{array}$ & $\begin{array}{l}\text { Psychiatric } \\
\text { Disorder } \\
(\mathrm{n}=100)\end{array}$ & $\begin{array}{l}\text { Psychiatric } \\
\text { Disorder } \\
\text { Absent }(\mathrm{n}=100)\end{array}$ & Total \\
\hline $\begin{array}{l}\text { Tonic-Clonic } \\
\text { All Other }\end{array}$ & $32[47 \%]$ & $40[53 \%]$ & $72[100 \%]$ \\
\begin{tabular}{l} 
Seizure \\
\hline
\end{tabular} & $12[42 \%]$ & $16[58 \%]$ & $28[100 \%]$ \\
\hline
\end{tabular}

Chi Square $=0.02 \mathrm{Df}=1 \mathrm{p}>0.05$ [Not Significant]

Table 17. Type Of Seizures $(N=100)$.

\begin{tabular}{|c|c|c|c|}
\hline Type of Seizure & $\begin{array}{l}\text { Psychiatric } \\
\text { Disorder } \\
\text { Present } \\
(n=44)\end{array}$ & $\begin{array}{l}\text { Psychiatric } \\
\text { Disorder } \\
\text { Absent } \\
(\mathrm{n}=56)\end{array}$ & $\begin{array}{l}\text { Total } \\
\text { Number }\end{array}$ \\
\hline COMPLEX FRONTAL & 4 & 4 & 8 \\
\hline COMPLEX TEMPORAL & 0 & 4 & 4 \\
\hline PARTIAL MOTOR & 2 & 0 & 2 \\
\hline PSYCHOMOTOR & 0 & 2 & 2 \\
\hline SENSORY-MOTOR & 0 & 2 & 2 \\
\hline SIMPLE MOTOR & 6 & 4 & 10 \\
\hline TONIC-CLONIC & 32 & 40 & 72 \\
\hline
\end{tabular}

Chi Square $=9.99 \quad \mathrm{Df}=6 \quad \mathrm{p}>0.05[$ Not Significant $]$

Type of Seizure: The majority of the patients had a primary generalized tonic-clonic seizure. The various types of seizures and the associated psychiatric morbidity are shown in Table 15 and 16. Psychiatric morbidity in patients with Tonic-Clonic Seizures was not statistically significantly increased when compared with all other seizure types, individually or as a group.

Table 18. Number Of Drugs For Seizure Control $(N=100)$.

\begin{tabular}{lllll}
\hline $\begin{array}{l}\text { No. of } \\
\text { Drugs }\end{array}$ & $\begin{array}{l}\text { Total } \\
\text { Patients }\end{array}$ & $\begin{array}{l}\text { Psychiatric } \\
\text { Disorder } \\
\text { Present }\end{array}$ & $\begin{array}{l}\text { Psychiatric } \\
\text { Disorder } \\
\text { Absent }\end{array}$ & $\begin{array}{l}\text { Stratum } \\
\text { Odds } \\
\text { Ratio }\end{array}$ \\
\hline 0 & 12 & 2 & 10 & 1.00 \\
1 & 74 & 30 & 44 & 3.14 \\
2 & 12 & 12 & 0 & 5.00 \\
3 & 2 & 0 & 2 & \\
Total & 100 & 44 & 56 & \\
\hline
\end{tabular}

Chi Square Linear Trend $=3.22 \mathrm{P}$ value $=0.07282$ [Not Significant]

Number of Drugs: Most of the patients were on monotherapy. The distribution of number of drugs is shown in Table 17. While the Odds ratio for having a psychiatric morbidity increased with the number of drugs needed to obtain seizure control, the linear trend merely approached levels of significance.

\section{Discussion}

The age of the sample varied from 18 to 50 years according to the study design as shown in Table 1 . The majority (58\%) was in the 18-32 age group with mean of 31.83 years [SD.9.46] in Group A, 31.81 years [SD 8.97] in group B and 31.76 years [SD 8.85] in group C.

The psychiatric morbidity ranged from $20 \%$ in the above age 46 group to $80 \%$ in the $>39-46$ group [Table 2]. Fiordelli et al [43] too, reported a rising odds ratio for prevalence of psychiatric disturbance until 44 years, and a decline thereafter. The highest prevalence of psychiatric disorder $(28 / 54 ; 51.85 \%)$ was in the age group $25-39$ years. This may be because depressive illnesses constituted the largest proportion amongst epileptics with psychiatric disorders. The onset of mood disorders per se is commonly reported in the 20-40 year olds [113].

There were $82 \%$ males and $18 \%$ female in each of the groups as depicted in Table 3. The disproportionate representation was in part due to the nature of the dependent population of the hospital. The difference in the psychiatric morbidity in males and females was not statistically significant as depicted in Table 4 . However, in view of the disproportionate sex distribution, this finding needs to be interpreted with caution. Ninety three percent subjects of all the group were educated, and $2 \%$ had post graduate / professional qualifications (Table 5). The psychiatric morbidity ranged from $18 \%$ in the subjects who had studied until tenth class to $85 \%$ amongst the uneducated subgroup (Table 6). The difference was highly significant. Amongst the patients whose epilepsy had started before the age of 25 years, $57 \%$ had studied beyond Class 10 as shown in Table 7. Thus, the onset of epilepsy was probably not responsible for their low educational status. The socioeconomic distribution of the three groups is given in Table 8. The socioeconomic status was based on the recommendations of Gupta et al (1990) [116], that are based on the educational status, occupation and the percapita family income. A majority in all the groups ( $84 \%$ in Group A, 76\% in Group B) was in the Lower Middle Socio-economical Strata.

The psychiatric morbidity ranged from none in the Upper Socio-economic group to $100 \%$ in the lower socioeconomic group as depicted in Table 9. However, the chisquare for linear trend was 2.088 and $p=0.148$ which is not significant. The stratum odds ratio showed 7.5 times chances that people from the lower strata of society would develop a psychiatric disorder. A limitation in the interpretation would be the uneven socio-economic distribution of the sample. The duration of epilepsy varied from a week to 27 years as depicted in Table 10. The chi square value for the analysis of linear trend was 4.01 at $\mathrm{p}<0.05$ (significant). However, the stratum odds ratio gradually increased until five years' illness, it dropped by nearly a third in the over five-year bracket.

GHQ score of less than five was regarded as normal. In the sample studied, rising GHQ score above five gave a chi 
square for linear trend as 8.87 at a $\mathrm{p}<0.01$, that was highly significant. The difference between Epilepsy patients and the normal group was very highly significant. The Stratum odds ratio, as depicted in table13, showed a rising trend till GHQ score of twenty, but then dropped to 2.86 when Leprosy patients were compared with the study group. This perhaps reflects equivocal psychiatric morbidity at these scores as detected by the instrument.

A possible psychiatric disorder was present in $44 \%$ of the epileptic group (Group A) as shown in Table 13 and 14. This morbidity is comparable to the study by Kogeorgos [32] that found $45.5 \%$ probable psychiatric cases after evaluation with the GHQ. The criteria used for that study group were similar to the present study. The study, however, unlike the present one, had $75 \%$ patients with temporal lobe epilepsy.

The present study found a total psychiatric morbidity of $19 \%$ in patients with Leprosy (Group B). The difference between Group A (Epilepsy) and Group B was highly significant (chi square $=14.482<0.001$ ). Most of the subjects in Group B did not have any physical deformity. Their illness, as depicted in Table 11 ranged from less than a month to 4 years for patient. Out of the 19 patients having a psychiatric disorder, nine had depression (63\%) including one patient who had depression with psychotic features as shown in Table 15. Affective symptomatology was present in $17(89.47 \%)$ of them. The commonest diagnosis was Moderate Depressive Episode with somatic syndrome [F 32.11 ] in $15 \%$ of the patients with epilepsy as shown in Table 15. Disorders with affective symptomatology comprised the largest group of illnesses [30\%]. There were no females with depression. Women tend to seek psychiatric assistance for the depression early [113], and were probably excluded from this study. It may be possible that this important life event-being diagnosed as an epileptic-has played some role in the genesis of affective disorder. Stressful events are also associated with the persistence of depressive disorders [113]. The prevalence of depressive disorders in Group A (15\%) is less than that reported in the national co morbidity Study [113]. The prevalence is, however, much higher than the control Group $\mathrm{C}$ that was age sex and education matched. In the absence of any other confounding variable, the role of epilepsy in depression may be causal.

A majority of the patients [72\%] had primary generalized tonic-clonic seizures as shown in Table 16, 17. In this study the psychiatric morbidity was independent of the type of seizure (Table 16, 17). Even when all types of seizures other than primary GTCS were combined, the difference was not statistically significant.

The psychiatric morbidity correlated with the increasing number of drugs needed to obtain optimum seizure control as shown in Table 18. All the patients who were on two drugs had a psychiatric disorder. There were only two patients on three drugs and they did not have a psychiatric disorder. Though the $p$ value $(0.7282)$ was not significant, the analysis for Stratum Odds ratio gave an unequivocal rising trend that conclusively proved an association with the increasing number of drugs. It is also possible that more number of drugs to achieve seizure control reflects continued seizure activity, which may in itself lead to increased psychiatric morbidity. The latter variable has not been addressed in the present study.

Most of the subjects in the present study were on monotherapy and the serum levels of medication were not assayed. Further, changes in the therapeutic regimen, if any, during the course of the illness were not addressed.

\section{Conclusion}

The present study was carried out to assess the psychiatric morbidity in a group of patients with epilepsy. It was then compared to a group of age, sex and education matched controls- patients with leprosy and similarly matched normal individuals. The findings can be summarized as under:

1. There was prevalence of $44 \%$ syndromal level psychiatric morbidity in patients with epilepsy, $68.1 \%$ of the psychiatric disorders was constituted by disorders with depressive symptoms.

2 . There were only $2 \%$ cases of psychosis.

3. Patients with epilepsy had a significantly higher psychiatric morbidity than patients with leprosy (44\%vs19\%)

4. The psychiatric morbidity was maximal in the 25-39 year age group, independent of the gender and correlated inversely with higher education and Socioeconomic status.

5. The psychiatric morbidity was independent of the type of seizure.

6. The psychiatric morbidity in epilepsy was maximal until the first five years of illness.

7. The morbidity increased with the number of drugs needed to control seizures.

\section{Limitations}

1. This study did not focus on and correlate the psychiatric morbidity with the following variables- specific drugs, duration since the last seizure and the laterality of the seizure.

2. Personality Disorders could not be studied as the instrument to detect the nature of psychiatric morbidity; SCAN does not address this question.

\section{Recommendations}

A similar study may be carried out in a larger sample keeping in view the aforementioned limitations and correlating the psychiatric disorders with functional neuroimaging techniques.

\section{Intellectual Contribution of Author}

Study Concept: Dr Amitabh Saha, MD Psychiatry 


\section{References}

[1] Epilepsy and related disorders. W G Lennox. Vol1. Little Brown and Company 1960, Boston 13- 31.

[2] D Hill. Historical Review. In: Reynolds and M Trimble, editors. Churchill and Livingstone 1981, Edinburgh 1-10

[3] P Fenwick. 1981. EEG Studies. In E Reynolds and M Trimble, editors. Churchill and Livingstone 1981, Edinburgh 145- 184.

[4] Perez MM and Trimble MR. Epileptic Psychosis: diagnostic comparison with process Schizophrenia. British Journal of psychiatry, 1980, 137: 245- 249.

[5] Scott DF Psychiatric aspects of epilepsy. British Journal of Psychiatry, 1978, 132: 417- 430.

[6] Gunn J and Fenton GW epilepsy, automatism and crime. Lancet I 1971: 1173-1176.

[7] SE Dubin, A Kuczmierczyk, J Aananth. Catatonic Stupor and Temporal lobe epilepsy. Indian Journal of Psychiatry. 1985; 27 [3]: 259-161.

[8] Drake and Coffee. Complex partial States simulating psychogenic unresponsiveness. American Journal of Psychiatry: $140 ; 800-801$.

[9] JS Duncan, SD Shorvon, DR Fish. Clinical Epilepsy. Churchill Livingstone. London. 1995. Page 326.

[10] Pond DA and Bidwell BH. A study of epilepsy in 14 GPs II Social and Psychological aspects. Epilepsia; 1960: 1 285299.

[11] Goldberg D, Huxley P 1980 Mental illness in the community. Tavistok London.

[12] RD Adams, M Victor, AH Ropper, Principles of Neurology. Sixth Edition 1997. McGraw-Hill. New York. Page 311.

[13] A Textbook of Epilepsy. Editors J Laidlow, A Richens. Churchill Livingstone. Edinburgh. 1976. Page 145
[14] Jensen I, Larsen JK. Mental aspects of temporal lobe epilepsy. Journal of Neurology Neurosurgery Psychiatry $1979 ; 42: 256-265$

[15] Mendez MF, Cummings JL, Benson F. Depression In Epilepsy: significance and phenomenology. 1986. Archives of Neurology; 43: 440-446.

[16] Robertson MM 1989. Organic contribution to depressive illness in epilepsy. Journal of Epilepsy: 2; 189-220

[17] Williams D. The structure of emotion reflected in epileptic experiences. Brain 1956; 79: 29-67.

[18] EBE Fiordelli, EttoreBeghi, Graziella Ogliun and Vittorio Crespi 1993. Epilepsy and psychiatric disturbance, a crosssectional study. British Journal of psychiatry: 163: 446-450.

[19] Barraclough B. Suicide and epilepsy. In Reynolds EH, Timble MR eds. Epilepsy and Psychiatry. Edinburgh Churchill Livingstone, 1981:72-76

[20] Bets TA. Psychiatry and epilepsy. In Laidlaw J, Richens A, eds. A textbook of Epilepsy Edinburgh. Churchill Livingstone, 1982: 227-270.

[21] Scott JS, Masland R L 1953 Occurrence of 'continuous symptoms' in epilepsy patients. Neurology 3:297-301.

[22] Scott JS, Masland R L 1953 Occurrence of 'continuous symptoms' in epilepsy patients. Neurology 3:297-301.

[23] Rennick M, Perez-Borja C, Rodin E A 1969 Transient mental deficits associated with recurrent prolonged epileptic clouded state. Epilepsia 10:397-405.

[24] Toone B. In Epilepsy and Psychiatry, Eds. Reynolds EH, Trimble MR, Churchill Livingstone, 1981. Pg.113.

[25] Scott JS, Masland R L 1953 Occurrence of 'continuous symptoms' in epilepsy patients. Neurology 3:297-301.

[26] Swamy HS, Mallikajunaih M, Bhatti KS and Kaliaperumal VG. A study of epileptic psychosis-150 cases using GHQ. Indian Journal of Psychiatry. 1986: 28[3]; 231- 236. 